\title{
Adolescent Male Attitudes About Singing in Choir
}

\author{
Mark Lucas'
}

\begin{abstract}
The purpose of this study was to investigate the factors that influence adolescent males to enroll in school choir as an elective class and to assess their attitudes about singing in general, self-concept of their own voices, and perception of others' view of adolescent males' participation in choir. Data were obtained from $10 \mathrm{I}$ adolescent males who were enrolled in choir at one of six participating schools, and were in Grade 7 or Grade 8. Data analysis showed that most participants enrolled in choir because they thought it was fun and/or they were good singers. Results also indicated that peer pressure factored less than the enjoyment of singing in influencing their decision to enroll in choir. Other results suggested that the participants perceived support from their families, principals, and nonmusic teachers in their decision to take choir and that they perceived slightly less support from coaches at their school. The study indicates a need for future research of adolescent males who have chosen not to participate in choir and their attitudes about choir participation. Future research studying the attitudes of adolescent males from other regions and their attitudes about choir participation is also recommended.
\end{abstract}

\section{Keywords}

adolescent, male, choir, motivation, attitude, self-efficacy, perception

\section{Introduction}

Junior high music teachers are well aware of the troubles inherent in recruiting and retaining male singers (Freer, 2007; Gates, 1989; Miziner, 1993; Pogonowski, 1985; White \& White, 2001). Boys at this age are perceived to have less interest in singing than girls of the same age (Miziner, 1993). The fact that typical adolescent behavior can frustrate even the best teacher makes the job of a junior high choir teacher extremely difficult at times (Williamson, 2000). Adolescent boys sometimes struggle with the difficulty of continuing to sing while dealing with a changing voice (Kennedy, 2002; Sandene, 1994) and perceived pressures from peers who may or may not believe participating in choir is "cool" (White \& White, 2001, p. 40).

Given these hurdles to overcome, it becomes even more important that adolescent singers, and adolescent males in particular, experience singing as an exciting, enjoyable activity and have "positive group experiences in ensembles with music they enjoy" (Phillips, 1994, p. 24). While published research is abundant in the areas of motivation, attitude, attrition of students who participate in music, and the boy's changing voice, the following review will show that little research has been specifically aimed at adolescent males who participate in choir and why they do so. Two notable exceptions to this are the works of Harrison (2004), and Freer, whose recent research in this area would be beneficial to any researcher or practitioner who works with adolescent males singers (2010, 2009a, 2009b, 2008, 2007).

\section{Review of the Literature}

How comfortable a student, particularly a male student, feels may affect attitudes about singing. George (1993) states "the most heavily used positive descriptor of anything young adolescents experience, particularly in reference to school, is fun" (p. 21). Whether studying fifth-grade band students (Klinedinst, 1991), junior high choir students (Callistro-Clements, 2002; Kennedy, 2002), high school choir students (Neill, 1998), or college choir students (Sichivitsa, 2001), research shows that the major underlying reason why students sing and or participate in music classes is that they enjoy it. Miziner (1993) states that "greater enjoyment of singing through improved singing

'University of Oklahoma, Norman, OK, USA

\section{Corresponding Author:}

Mark Lucas, School of Music, University of Oklahoma, 500 W. Boyd, Room 138, Norman, OK 73019, USA

Email: lucas@ou.edu 
skill might be assumed to lead to a more positive attitude toward music and toward participation in choir" (p. 234). Research has also indicated that a student who was confident in music because of success would have a positive attitude toward music (Siebenaler, 2006; Svengalis, 1978). Klinedinst (1991) states that "self-concept in music ... play(s) a prominent role" in student retention. (p. 236). Data from a 2002 study by Callistro-Clements indicated that musical self-concept and positive attitude toward music were two areas in which there was a significant difference between those who chose to be in choral music class and those who did not. Neill (1998) noted that "students' overall responses revealed that enrollment in chorus resulted from a love of singing" and that "the least powerful influence was friends' decision to participate" (p. 1105). In a study examining attitudes of college choir members, Sichivitsa indicates students reported they were interested in college choir for intrinsic reasons (2001). They simply enjoyed singing and making music.

Gender influences have been shown to affect attitudes of adolescent males toward singing. In a study of student beliefs about what causes success and failure in music, Asmus (1986) observed Grade 4 to Grade 12 students enrolled in music courses. He discovered that although $80 \%$ of reasons for success cited by students were internal in nature, females cited more internal reasons than males. In describing the relationship between junior high and all other students, he states, "Junior high school students responded with a greater number of external-stable attributions while citing reasons for failure in music while all other schools made greater external-stable attributions when citing reasons for success in music" (Asmus, 1986, p. 275). When studying middle and junior high school general music students, Boswell (1991) found that gender affected attitudes. In Boswell's study, participants indicated a positive attitude about understanding what goes on in general music class, about the effort necessary to participate, and about being treated equally, but they indicated that they did not feel important or look forward to music class nor did they feel challenged by the class. Males revealed a tendency to have a less positive attitude toward music class and or singing in general. Pogonowski (1985) studied the attitudes of upper elementary students and found that there was a more marked decline in positive attitude toward music class for males than for females. Attrition in choir participation tends to occur from the elementary level to the secondary level, and girls generally have a more positive attitude toward music than boys (Miziner, 1993). Male involvement in choirs has declined in recent years, and the recruitment and retainment of male singers, especially in junior high, is extremely difficult. Phillips (1992) states that "maintaining boys' active interest in singing during the adolescent years is a major challenge to music educators" (p. 75). Gates (1989) maintains that there has been a shift from colonial times when males dominated the American singing environment to the present when "adolescent and adult males are much less involved with public singing than are females" (p. 33). Miziner (1993) studied elementary school children and found that "a smaller percentage of boys (64\%) than girls $(87 \%)$ gave a positive response to the question 'Do you like to sing" "and that "a significantly greater proportion of girls (55\%) than boys (33\%) wanted to sing in a choir" (p. 236).

Other outside influences can affect the enrollment of adolescent males in choir. Research shows that among other age groups, intrinsic value is the most important factor influencing participation in music. But parents and teachers of adolescent males may have less influence on their children than do other children. George (1993) states, "Adolescents are more likely to be influenced by their peers than by adult authority" (p. 21). However, the adolescent male student's attitude toward music may be influenced by the extent of family activity in music. Svengalis (1978), when studying music attitude and the preadolescent male, found that males with a high selfconcept in music tend to come from a home with a high level of music activity. Sichivitsa (2001) found when studying reasons a college choir member remains in an ensemble that parental musicianship had less of an impact on the participants' intentions to continue with the class than did parental support.

Research into motivation and retention of students in instrumental music reveals several factors influencing a student's decision to stay in a performing ensemble. Some researchers believe that external reasons, including family, peer pressure, and relationships between students and between the student and teacher play an important role in retaining ensemble members (Klinedinst, 1991). Corenblum and Marshall (1998) concluded that ninth-grade band students were more likely to enroll in band if they had received a favorable evaluation from their director. The researchers also found that other factors not measured, such as nonmusical extracurricular activities, may influence intentions.

The foregoing review has revealed a need for the study of adolescent males' attitudes about singing in choir. Therefore the purpose of the present study was to investigate adolescent males' attitudes about singing in choir. Specifically, the study was designed to investigate issues influencing adolescent males to enroll in school choir as an elective class and to assess their attitudes about singing in general, their own voices in particular, and their perceptions of how teachers, coaches, administration, and family view the participation of adolescent males in choir. In this article, the term junior high is defined as students enrolled in Grades 7 and 8. Obviously, the middle school is a counterpart to the junior high, and differences in the sociocultural structures between the two might affect student attitudes toward singing. However, students in 
Grades 7 and 8 are common to both schools; therefore, environmental and social factors that may be present between the two institutions were determined to have little impact on the results of the study.

In this survey study, five research questions were used:

What factors most influence adolescent males to enroll in choir? (Nine survey items)

What are adolescent males' perceptions of how their peers feel about guys singing in choir? (Four survey items)

What are adolescent males' perceptions of how their teachers, coaches, and administration feel about guys singing in choir? (Three survey items)

What are adolescent males' perceptions of how their families feel about singing in choir? (Four survey items)

How do adolescent males view their singing ability, and how do they view singing in choir? (Four survey items)

\section{Method and Procedure}

\section{Instrument}

Constructed with the support of similar studies found from a review of related literature, a survey was developed and submitted to 12 experienced public school and university music educators for review. After receiving evaluations and suggestions from these experts about item content, questionnaire structure, and the fulfillment of research objectives, recommended and appropriate modifications to the survey instrument were made. Items were revised for clarity, and a pool of more than 40 initial statements was reduced to 28 items for the final version of the survey. Cronbach's alpha determined the reliability of the survey items, and the survey was found to be internally consistent (.793).

The survey comprised two sections. The first section contained four questions covering age, grade level, playing a music instrument, and participation in band. The second section comprised 24 statements in a 4-point Likert-type scale. These items, written specifically to assess the five research questions, were placed randomly throughout this portion of the survey to avoid a response set.

\section{Procedure}

The researcher contacted junior high choir teachers from schools in Kansas and Oklahoma to identify interest for participating in the study. Schools were selected because of their range of population and geographical area and because the researcher was acquainted with the teacher at each school. Teachers from six schools agreed to participate.
The researcher computed descriptive statistics and chisquares. A nonparametric procedure (chi-square) was determined to be the appropriate analytical procedure because of the limited categorical nature of the 4-point Likert-type scale and skewing of the results.

\section{Participants}

A total of 101 students enrolled in the seventh- or eighthgrade choir at one of six schools in Kansas and Oklahoma, returning signed parental or legal guardian permission forms and student assent statements, completed the survey. Of the six participating schools, four were from Kansas and two were from Oklahoma. The mean age of students was 13.77 years. Forty of the participants were currently in Grade 7, whereas 61 participants were in Grade 8. Thirty-four participants were presently enrolled in band at their school, whereas 66 were not enrolled. Each of the schools had both a band and a choir, but not all six had an orchestra. Therefore, data from students in that area were not obtained.

\section{Results}

A subjective assessment of the schools indicated similarities in student profiles, school structure, and socioeconomic conditions to the extent that equality among variables was considered sufficient, thus allowing data to be collapsed across schools for purposes of reporting and analysis.

Tables 1 through 5 show means and standard deviations for each of the five research questions by grade and number, with data collapsed across schools. Also included in the tables are the means and standard deviations of participants in Grade 7, participants in Grade 8, and participants who indicated they were or were not enrolled in band.

Results in Table 1 show that the two statements with the highest means, across both grade levels and band participation, are distinguished by the categories of choir being "fun" and the participant's perceived ability. The two statements with the lowest means are revealed to be in categories of perceived influences of the participant's family and other adolescent males.

Table 2 shows that the participants generally perceived support from their peers in relation to singing in choir but that they agreed that the most popular students in their school participate in choir, albeit popular females more than popular males.

Results in Table 3 show that participants perceived their principal and nonmusic teachers as supporting their participation in choir with their coaches supporting choir participation to a lesser degree.

Results from Table 4 show that the participants agreed that their families are supportive of their participation 
Table I. What Factors Most Influence an Adolescent Male to Enroll in Choir? (Nine Survey Items)

\begin{tabular}{|c|c|c|c|c|c|c|c|c|c|c|c|}
\hline \multirow[b]{2}{*}{ Item } & \multirow[b]{2}{*}{ Survey Statement } & \multicolumn{2}{|c|}{$\begin{array}{l}\text { Grade } 7 \\
(n=40)\end{array}$} & \multicolumn{2}{|c|}{$\begin{array}{l}\text { Grade } 8 \\
(n=61)\end{array}$} & \multicolumn{2}{|c|}{$\begin{array}{c}\text { Band } \\
(n=34)\end{array}$} & \multicolumn{2}{|c|}{$\begin{array}{l}\text { No Band } \\
(n=66)\end{array}$} & \multicolumn{2}{|c|}{ All $(n=|0|)$} \\
\hline & & Mean & $S D$ & Mean & $S D$ & Mean & $S D$ & Mean & $S D$ & Mean & $S D$ \\
\hline 23 & $\begin{array}{l}\text { I am in choir because of the } \\
\text { other guys in my school. }\end{array}$ & 1.88 & 0.94 & 2.00 & 1.07 & $2.12 *$ & 0.96 & $1.88 *$ & 1.04 & 1.95 & 1.01 \\
\hline 8 & $\begin{array}{l}\text { I am in choir because of the } \\
\text { girls in my school. }\end{array}$ & 1.98 & 1.05 & 2.20 & 1.15 & 2.15 & 1.05 & 2.11 & 1.15 & 2.11 & I.II \\
\hline 20 & $\begin{array}{l}\text { I am in choir because I am } \\
\text { good at it. }\end{array}$ & 3.22 & 1.05 & 2.87 & 1.07 & 3.27 & 0.91 & 2.91 & I.II & 3.01 & 1.07 \\
\hline 21 & I am in choir because it is fun. & 3.35 & 1.03 & 3.00 & 1.07 & 3.52 & 0.67 & 2.98 & 1.16 & 3.14 & 1.06 \\
\hline 22 & $\begin{array}{l}\text { I am in choir mainly because } \\
\text { my family wants me to be } \\
\text { in choir. }\end{array}$ & 1.90 & 0.97 & 1.86 & 0.92 & 2.12 & 0.99 & 1.73 & 0.88 & I.88 & 0.93 \\
\hline 19 & $\begin{array}{l}\text { I take choir because it is an } \\
\text { easy class. }\end{array}$ & 2.41 & 1.21 & 2.55 & 1.16 & 2.45 & 1.18 & 2.52 & 1.19 & 2.49 & 1.17 \\
\hline 18 & $\begin{array}{l}\text { If a coach told the boys in my } \\
\text { school to sing in choir we } \\
\text { would have a lot more boys } \\
\text { in choir. }\end{array}$ & 2.64 & 1.16 & 2.37 & 1.15 & 2.79 & 1.17 & 2.31 & 1.13 & 2.47 & 1.15 \\
\hline 7 & $\begin{array}{l}\text { If my principal told the guys } \\
\text { in my school to sing in choir } \\
\text { we would have a lot more } \\
\text { guys in choir. }\end{array}$ & 2.55 & I.II & 2.33 & 1.23 & 2.59 & 1.10 & 2.35 & 1.22 & 2.42 & 1.18 \\
\hline 24 & $\begin{array}{l}\text { I am in choir because of the } \\
\text { choir director/teacher. }\end{array}$ & 2.25 & 1.15 & 2.46 & 1.16 & $2.70^{*}$ & 0.98 & $2.23^{*}$ & 1.21 & 2.37 & 1.16 \\
\hline
\end{tabular}

$*_{p}<.05$. Pearson chi-square indicated significance at the .05 level.

Table 2. What Is an Adolescent Male's Perception of How His Peers Feel About Guys Singing in Choir? (Four Survey Items)

\begin{tabular}{|c|c|c|c|c|c|c|c|c|c|c|c|}
\hline \multirow[b]{2}{*}{ Item } & \multirow[b]{2}{*}{ Survey Statement } & \multicolumn{2}{|c|}{$\begin{array}{l}\text { Grade } 7 \\
(n=40)\end{array}$} & \multicolumn{2}{|c|}{$\begin{array}{l}\text { Grade } 8 \\
(n=6 I)\end{array}$} & \multicolumn{2}{|c|}{$\begin{array}{c}\text { Band } \\
(n=34)\end{array}$} & \multicolumn{2}{|c|}{$\begin{array}{l}\text { No Band } \\
(n=66)\end{array}$} & \multicolumn{2}{|c|}{ All $(n=|0|)$} \\
\hline & & Mean & $S D$ & Mean & $S D$ & Mean & $S D$ & Mean & $S D$ & Mean & $S D$ \\
\hline I & $\begin{array}{l}\text { The girls in my school } \\
\text { think it's good for guys } \\
\text { to sing in choir. }\end{array}$ & 3.19 & 0.81 & 3.03 & 0.95 & 3.34 & 0.81 & 3.02 & 0.89 & 3.09 & 0.90 \\
\hline 5 & $\begin{array}{l}\text { The guys in my school } \\
\text { think it's good for guys } \\
\text { to sing in choir. }\end{array}$ & 2.79 & 1.00 & 2.71 & 1.01 & 2.97 & 0.82 & 2.66 & 1.06 & 2.74 & 1.00 \\
\hline 9 & $\begin{array}{l}\text { The most popular guys in } \\
\text { my school sing in choir. }\end{array}$ & 3.20 & 1.07 & 3.08 & 1.15 & $3.63 *$ & 0.75 & $2.92 *$ & 1.17 & 3.13 & I.II \\
\hline 14 & $\begin{array}{l}\text { The most popular girls in } \\
\text { my school sing in choir. }\end{array}$ & 3.26 & 0.94 & 3.30 & 1.01 & 3.61 & 0.79 & 3.12 & 1.03 & 3.28 & 0.98 \\
\hline
\end{tabular}

$*_{p}<.05$. Pearson chi-square indicated significance at the .05 level.

in choir, but they did not agree that their family sings together. Rather the results indicate some measure of enjoyment of family singing.

Results from Table 5 show that participants believed they were good singers and that singing in choir is an enjoyable activity for them. Results also show that they did not believe their participation in choir resulted in a loss of friends.

\section{Discussion and Conclusions}

\section{What Factors Most Influence Adolescent Males to Enroll in Choir?}

Nine survey items were used for purposes of assessing the content items of this question (see Table 1). The survey statement "I am in choir because it is fun" had the highest mean (3.14) of the nine items assessing this research 
Table 3. What Is an Adolescent Male's Perception of How His Teachers, Coaches, and Administration Feel About Guys Singing in Choir? (Three Survey Items)

\begin{tabular}{|c|c|c|c|c|c|c|c|c|c|c|c|}
\hline \multirow[b]{2}{*}{ Item } & \multirow[b]{2}{*}{ Survey Statement } & \multicolumn{2}{|c|}{$\begin{array}{l}\text { Grade } 7 \\
(n=40)\end{array}$} & \multicolumn{2}{|c|}{$\begin{array}{l}\text { Grade } 8 \\
(n=61)\end{array}$} & \multicolumn{2}{|c|}{$\begin{array}{l}\text { Band } \\
(n=34)\end{array}$} & \multicolumn{2}{|c|}{$\begin{array}{l}\text { No Band } \\
(n=66)\end{array}$} & \multicolumn{2}{|c|}{ All $(n=101)$} \\
\hline & & Mean & $S D$ & Mean & $S D$ & Mean & $S D$ & Mean & $S D$ & Mean & $S D$ \\
\hline 2 & $\begin{array}{l}\text { My nonmusic teachers think it is } \\
\text { good for guys to be in choir. }\end{array}$ & $3.50 *$ & 0.51 & $3.14 *$ & 0.79 & $3.34^{*}$ & 0.81 & $3.32 *$ & 0.79 & 3.28 & 0.71 \\
\hline 10 & $\begin{array}{l}\text { My principal thinks it is good for } \\
\text { guys to be in choir. }\end{array}$ & 3.39 & 0.73 & 3.41 & 0.83 & 3.52 & 0.63 & 3.38 & 0.81 & 3.40 & 0.79 \\
\hline 16 & $\begin{array}{l}\text { The coaches at my school think it is } \\
\text { good for buys to be in choir. }\end{array}$ & $3.15^{*}$ & 0.89 & $2.63^{*}$ & 0.96 & 3.19 & 0.75 & 2.69 & 1.01 & 2.83 & 0.98 \\
\hline
\end{tabular}

$*_{p}<.05$. Pearson chi-square indicated significance at the .05 level.

Table 4. What Is an Adolescent Male's Perception of How His Family Feels About Singing in Choir? (Four Survey Items)

\begin{tabular}{|c|c|c|c|c|c|c|c|c|c|c|c|}
\hline \multirow[b]{2}{*}{ Item } & \multirow[b]{2}{*}{ Survey Statement } & \multicolumn{2}{|c|}{$\begin{array}{l}\text { Grade } 7 \\
(n=40)\end{array}$} & \multicolumn{2}{|c|}{$\begin{array}{l}\text { Grade } 8 \\
(n=6 I)\end{array}$} & \multicolumn{2}{|c|}{ Band $(n=34)$} & \multicolumn{2}{|c|}{$\begin{array}{l}\text { No Band } \\
(n=66)\end{array}$} & \multicolumn{2}{|c|}{ All $(n=101)$} \\
\hline & & Mean & $S D$ & Mean & $S D$ & Mean & $S D$ & Mean & $S D$ & Mean & $S D$ \\
\hline 3 & $\begin{array}{l}\text { My family thinks it } \\
\text { is good that I am } \\
\text { in choir. }\end{array}$ & 3.69 & 0.52 & 3.51 & 0.57 & 3.73 & 0.45 & 3.52 & 0.59 & 3.58 & 0.55 \\
\hline 6 & $\begin{array}{l}\text { My family sings } \\
\text { together. }\end{array}$ & 1.87 & 1.06 & 1.75 & .91 & $2.15^{*}$ & 1.12 & $1.64 *$ & 0.83 & 1.80 & 0.96 \\
\hline 12 & $\begin{array}{l}\text { My family rarely } \\
\text { sings together. }\end{array}$ & 3.00 & 1.21 & 3.31 & 0.96 & 3.03 & 1.19 & 3.27 & 1.02 & 3.19 & 1.07 \\
\hline 15 & $\begin{array}{l}\text { The people in my } \\
\text { family like to sing. }\end{array}$ & $3.20 *$ & 1.07 & $2.69 *$ & 1.10 & $3.29 *$ & 1.03 & $2.7 I^{*}$ & 1.09 & 2.89 & I.II \\
\hline
\end{tabular}

$*_{p}<.05$. Pearson chi-square indicated significance at the .05 level.

Table 5. How Does an Adolescent Male View His Singing Ability and How Does He View Singing in Choir? (Four Survey Items)

\begin{tabular}{|c|c|c|c|c|c|c|c|c|c|c|c|}
\hline \multirow[b]{2}{*}{ Item } & \multirow[b]{2}{*}{ Survey Statement } & \multicolumn{2}{|c|}{$\begin{array}{l}\text { Grade } 7 \\
(n=40)\end{array}$} & \multicolumn{2}{|c|}{$\begin{array}{l}\text { Grade } 8 \\
(n=61)\end{array}$} & \multicolumn{2}{|c|}{ Band $(n=34)$} & \multicolumn{2}{|c|}{$\begin{array}{l}\text { No Band } \\
(n=66)\end{array}$} & \multicolumn{2}{|c|}{ All $(n=101)$} \\
\hline & & Mean & $S D$ & Mean & $S D$ & Mean & $S D$ & Mean & $S D$ & Mean & $S D$ \\
\hline 4 & I am a good singer. & 3.25 & 0.93 & 2.97 & 1.08 & $3.35 *$ & 0.88 & $2.97 *$ & 1.05 & 3.08 & 1.03 \\
\hline II & I am a poor singer. & 1.79 & 0.89 & 2.21 & 1.10 & 1.94 & 0.86 & 2.12 & 1.12 & 2.05 & 1.04 \\
\hline 13 & $\begin{array}{l}\text { I think singing in } \\
\text { choir is fun. }\end{array}$ & 3.45 & 1.01 & 3.10 & 1.12 & 3.53 & 0.75 & 3.12 & 1.18 & 3.24 & 1.09 \\
\hline 17 & $\begin{array}{l}\text { If I were not in } \\
\text { choir I would have } \\
\text { more friends. }\end{array}$ & 1.45 & 0.81 & 1.44 & 0.72 & 1.26 & 0.45 & 1.53 & 0.86 & 1.45 & 0.75 \\
\hline
\end{tabular}

${ }^{*} p<.05$. Pearson chi-square indicated significance at the .05 level.

question. These results support findings of Neill (1998), who found that among high school choir students, enrollment in chorus resulted from a love of singing; CallistroClements (2002), whose study indicated that a positive attitude toward music was a significant factor; Sichivitsa (2001), whose study of college choir students showed that students were interested in their college choir class for intrinsic reasons; and Kennedy (2002), who found that factors motivating junior high boys' membership in choir included a love of singing. The two lowest means for this research question were in relation to influences from family (1.88) and other adolescent males (1.95). This could be 
seen as contradictory to the opinion of White and White (2001) that perceived pressures of peers play a part in choir participation of adolescent males and research by Klinedinst (1991) and Siebenaler (2006) indicating that family support plays an important role in ensemble participation. However, the survey item referenced, concerning family was the statement "My family sings together." That statement does not necessarily reflect an influence on the student's participation in choir.

\section{What Are Adolescent Males' Perceptions of How Peers Feel About Guys Singing in Choir?}

Four items were used to assess this question (see Table 2). The data suggested that adolescent boys agreed that the most popular guys and girls in their schools sing in choir. The data also suggested that adolescent males perceived less support from their male than their female peers for singing in choir. This perception supports the conclusion by Pogonowski (1995) who found that upper elementary male students demonstrated a more serious decline in attitude toward music class than females.

\section{What Are Adolescent Males' Perceptions of How Their Teachers, Coaches, and Administration Feel About Guys Singing in Choir?}

Three items were used to assess this question (see Table 3). The data suggested that adolescent males in choir perceived their principal and nonmusic teachers as supportive of their participation in choir. Less positive were their perceptions of whether their coaches supported their choir participation. Students were directed to leave a statement blank if they were undecided. Ninety-five of 101 participants responded to items pertaining to their principal and nonmusic teachers, and 88 of 101 students responded to the item pertaining to coaches at their school.

\section{What Are Adolescent Males' Perceptions of How Their Families Feel About Singing in Choir?}

Four items were used to measure this question (see Table 4). The highest mean in the survey was in response to the statement "My family thinks it is good that I am in choir." Data suggested that these participants felt supported by family in their choir participation. The data also suggested that participants' families do not sing together. The students' perception of how much their families like to sing was more positive than their response to the statement "My family sings together." This may suggest that musical activity in the students' homes cannot be accurately measured by responses to this statement alone.

\section{How Do Adolescent Males \\ View Their Singing Ability and How Do They View Singing in Choir?}

Four items were used to assess this question (see Table 5). The participants agreed that they are good singers and that singing in choir is fun. This supports prior research that students who are confident in music because of success have a positive attitude toward music (Svengalis, 1978). These data may also support Klinedinst's (1991) research that self-concept in music plays an important role in student retention. Corenblum and Marshall (1998) found when studying reasons a ninth grader decides to stay in band that the more favorable the band teachers evaluated students' musical competency, the more likely students said they would take band the next year. Although students in the current study evaluated themselves rather than being evaluated by a teacher, the fact remains that they possessed a reasonably high self-concept of their singing ability, which may affect their decision to remain in choir.

George (1993) found that peers have more influence over adolescents than adults. In the current study, participants agreed that they felt supported by family, administration, and nonmusic teachers and that their most popular peers participated in choir but did not indicate that these factors were among the most influential in their decision to enroll in choir. The data suggested that the two most influential factors among those listed in the survey were their singing ability and the enjoyment of the class. The data did not suggest either conclusive support for or contradiction of George's statement.

\section{Additional Findings}

The data gathered seemed to suggest that students who also participate in band have a higher opinion of how "fun" choir is and felt that they are good singers. Students in band also had a more positive attitude in general than nonband members. Band members seemed to respond with a more positive opinion on most statements. In the first research question, the only statement band members did not rate higher than nonband members was "I take choir because it is an easy class." In fact, nonband members gave a more positive response than band members on only 4 of the 24 statements. Important to note, however, 
is that a Pearson chi-square indicated that only 7 of the 24 questions were significant at or beyond the .05 level (see Tables 1-5).

\section{Concerns}

The data gathered for this study represent only the attitudes of adolescent males who chose to participate in choir. Therefore, these data and findings should be used mainly for insight and retention purposes. To create viable recruitment strategies for males this age, more research is needed concerning adolescent males who do not choose to enroll in choir as a class in Grades 7 or 8 . The data from this study cannot be generalized to all boys in Grades 7 and 8 who participate in choir since no data were gathered from participants outside specific locations in the states of Oklahoma and Kansas. Further research in other areas of the country would be beneficial.

\section{Implications}

Results indicate that the participants believed the most popular students in their school are in choir but that they did not feel an absence of friends as a result of participating in choir. The attitude of the students seems to be a healthy one. Teachers often believe that if they recruit a few athletes or other highly regarded students from their school into choir, the result will be manifested in increased enrollment. This may be true, but data from this study cannot confirm this idea.

Perhaps most important, the data suggested that participants sing in choir because (a) they are good singers and (b) they enjoy singing. The word fun obviously holds a prominent place among the results of the current study, and the meaning is expected to be related more to interpretations as a challenging experience rather than a time to "goof off." Junior high choir directors should use positive male role models (Demorest, 2000) and challenging materials to create an environment of enjoyment for adolescent males in choir. Finally, data gathered in the study supported prior research findings with other age-groups. In general, the results support the premise that the most important factor influencing participation in choir of high schools and college students is the intrinsic enjoyment of singing (Neill, 1998; Sichivitsa, 2001). In other words, students participate in choir because they enjoy singing. A logical conclusion is that making choir an enjoyable experience is an important task for those who teach junior high choir. Formulating a definition of an enjoyable experience, however, is a more difficult task. Further research is needed to determine what makes singing in choir an enjoyable experience for junior high boys.

\section{Declaration of Conflicting Interests}

The author(s) declared no potential conflicts of interest with respect to the research, authorship, and/or publication of this article.

\section{Funding}

The author(s) received no financial support for the research, authorship, and/or publication of this article.

\section{References}

Asmus, E. P. (1986). Student beliefs about the causes of success and failure in music: A study of achievement motivation. Journal of Research in Music Education, 34(4), 263-278.

Boswell, J. (1991). Comparisons of attitudinal assessments in middle and junior high school general music. Bulletin of the Council for Research in Music Education, 108, 49-57.

Callistro-Clements, A. (2002). The importance of selected variables in predicting student participation in junior high choir (Doctoral dissertation, University of Washington). Dissertation Abstracts International: Section A. Humanities and Social Sciences, 63, 2819.

Corenblum, B., \& Marshall, E. (1998). The band played on: Predicting students' intentions to continue studying music Journal of Research in Music Education, 46(1), 128-140.

Demorest, S. (2000). Encouraging male participation in chorus. Music Educators Journal, 86(4), 38-41.

Freer, P. K. (2007). Between research and practice: How choral music loses boys in the "middle." Music Educators Journal, 94(2), 28-34.

Freer, P. K. (2008). Boys' changing voices in the first century of MENC journals. Music Educators Journal, 95(1), 41-47.

Freer, P. K. (2009a). Choral warm-ups for changing adolescent voices. Music Educators Journal, 95(3), 57-62.

Freer, P. K. (2009b). I'll sing with my buddies-Fostering the possible selves of male choral singers. International Journal of Music Education, 27, 341-355.

Freer, P. K. (2010). Two decades of research on possible selves and the "missing males" problem in choral music. International Journal of Music Education, 28(4), 17-30.

Gates, J. T. (1989). A historical comparison of public singing by American men and women. Journal of Research in Music Education, 37(1), 32-47.

George, P. S. (1993). The middle school-and beyond. Alexandria, VA: Association for Supervision and Curriculum Development.

Harrison, S. D. (2004). Engaging Boys: Overcoming Stereotypes-Another Look at the Missing Males in Vocal Programs. Choral Journal, 45(2), 24-29.

Kennedy, M. A. (2002). "It's cool because we like to sing:" Junior high school boys' experience of choral music as an elective. Research Studies in Music Education, 18, 26-36. 
Klinedinst, R. E. (1991). Predicting performance achievement and retention of fifth-grade instrumental students. Journal of Research in Music Education, 39(3), 225-238.

Miziner, C. P. (1993). Attitudes of children toward singing and choir participation and assessed singing skill. Journal of Research in Music Education, 41(3), 233-245.

Neill, S. L. (1998). Motivating factors for student participation in high school choral programs and vocal enrichment activities (Doctoral dissertation, University of Missouri-Kansas City). Dissertation Abstracts International: Section A. Humanities and Social Sciences, 59(04), 1105.

Phillips, K. (1992). Teaching kids to sing. New York, NY: Schirmer Books.

Phillips, K. (1994). Recruiting singers for elementary chorus. Teaching Music, 1(6), 24-25.

Pogonowski, L. M. (1985). Attitude assessment of upper elementary students in a process-oriented music curriculum. Journal of Research in Music Education, 33(4), 247-257.
Sandene, B. A. (1994). Going beyond recruiting: Fighting attrition. Music Educators Journal, 81(1), 32-34.

Sichivitsa, V. O. (2001). College choir members' motivation to persist in music: Application of the Tinto model (Unpublished doctoral dissertation). Auburn University, Auburn, AL.

Siebenaler, D. J. (2006). Factors that predict participation in choral music for high-school students. Research and Issues in Music Education, 4(1), 1-8.

Svengalis, J. N. (1978). Music attitude and the preadolescent male (Doctoral dissertation, The University of Iowa). Dissertation Abstracts International: Section A. Humanities and Social Sciences, 39(08), 4800.

White, C., \& White, D. K. (2001). Commonsense training for changing male voices. Music Educators Journal, 87(6), 39-43.

Williamson, S. (2000). Positively adolescent. Music Educators Journal, 86(4), 29-32. 